pediat. Res. 11: 87-89 (1977)

\title{
X. General Discussion
}

\author{
MARY ANN SOUTH, RAPHAEL WILSON, AND JOHN R. MONTGOMERY
}

Department of Pediatrics, Baylor College of Medicine, Houston, Texas, USA

It may be of interest to trace the history of the decision to place this child in isolation at birth, for that decision predated the conception of the child. After genetic counseling after the death of their first son, the parents understood the probabilities of having another child with SCID based on the various hereditary patterns of this defect. Although the data from the autopsy of their first son was consistent with the diagnosis of X-linked SCID, there was no way of knowing whether the mother was indeed a carrier of the defective gene or the first son's disease was the result of a new mutation (Section II). These parents, who wanted very much to have another child, especially a son, inquired what could be done for a future child that might have SCID. They already knew about bone marrow transplantation as a reconstitutive technique and they were fully aware of the necessity to control infection in patients who were candidates for transplantation. They were told of the procedure of germ free delivery, which had already been done in at least three other cases where there was a high risk of SCID, and they were informed of the availability of gnotobiotic isolation techniques which had been used to protect the German twins with immunodeficiency (49). On the basis of this information and the knowledge that the medical and research staff available to them were prepared to utilize these new technologies, they elected to have another child. The final decision to place the child in isolation at birth was made when amniocentesis during the seventh month of gestation indicated that the child was a male. Abortion was never an issue because the pregnancy was planned and the parents had already decided to take the risk of another SCID child. There was no way to diagnose SCID through amniocentesis, so the risk of aborting a normal child was very great. Therefore the time planned for the amniocentesis was too late for abortion, even if the parents had changed their minds. The decision of the research staff to place the child in isolation was based on confidence that the isolator would save the child from death by infection until reconstitution of the immune system could be made if the child should be immunodeficient. It was made in the optimistic hope that a donor would be available or that other means of conferring immunologic reactivity would become available in this rapidly expanding area of the field of immunology.

The cost of long term care of a patient under gnotobiotic conditions is great. Ordinarily, the justification for spending the funds for a patient with this condition in preference to patients with other life-threatening diseases should probably be made on the basis of the research rewards which will most benefit the whole population who, in the long run, bear the cost of the support. Most research endeavors are planned with these considerations in mind. Nevertheless, the alert scientist must pursue opportunities which are unexpectedly presented to him as well as planned endeavors. In the present situation it was not expected that the patient would need to be in the isolator so long. Nevertheless, in the evolution of this case unusual opportunity developed for research studies of the many aspects of this immune disorder separated from the effects of the infection. It also presented an opportunity to follow the general development of a child under unique conditions. Such studies have been carried out and are continuing.

It is, of course, urgent to pursue all means which might allow this child to be safely released from isolation. At the time of this writing, more than 30 patients have been successfully treated with bone marrow from matching siblings. Treatment of patients who have no matching sibling has rarely been successful. Reconstitution has been accomplished with bone marrow from matching nonsibling relatives but matching nonrelated persons have not yet been proven to serve as effective donors. Fetal tissues have offered another method of obtaining stem cells. In two cases, fetal thymus (2) and fetal thymus plus transfer factor (43) have producted T-cell reconstitution. Fetal liver has also produced reconstitution $(1,26,52)$, but at present there are two patients who have had only a short term survival after this procedure $(1,52)$. Certainly the treatment of patients who have no matched donor is not yet well enough established to furnish any assurance of success in $D V$.

A number of findings have indicated some degree of developing immune function in this child. (1) B-cell activity is indicated to a limited extent by the very low titers after KLH immunization, the detection of $7 \mathrm{~s}$ and $19 \mathrm{~s}$ material in the serum at 36 months, the detection of $\operatorname{IgA}$ at 39 months, and the disappearance of the $4 \mathrm{~s}$ component by 44 months. (2) He may have some T-cell activity, as would be indicated by the skin test response to $\mathrm{KLH}$, the transient skin test reactions after TF injections, the transient PHA responses, and his recent acquisition of E-rosetting cells in increasing numbers. (3) He shows low, but significant levels of certain nonspecific lymphocyte functions (i.e, lymphotoxin and migration inhibition factor). (4) The majority of his lymphocytes have changed from an entirely abnormal to an almost normal appearance by electron microscopy. (5) $\mathrm{He}$ has tolerated his bacterial flora without difficulty.

It is possible that these changes are no more than reflections of aberrant responses to antigenic stimulation of the essentially defective immune mechanisms, and not indicative of increasing functional activity. On the other hand, there is the possibility that they might reflect some degree of maturation which will eventually lead to immunologic responsiveness, as happened with the German twins.

It seems, therefore, that there are two reasons to proceed cautiously before deciding to employ a transplant procedure at this time: the possibility of producing a fatal GVH reaction in a person who is not presently in a life-threatening situation and the possibility of disrupting some process of improvement which may already be leading to his development of immunologic competence.

There is no reason to believe this child is suffering now from serious disadvantages in his physical, mental, or psychological development. He is healthy, active, outgoing, and keenly interested in all aspects of his environment. Every effort is being made to make his life as normal as possible under the circumstances. These efforts include allowing him to spend as much 
time as possible at home in a family situation, avoiding undue publicity by keeping the family name anonymous in press reports, teaching him about outside life through pictures and real objects which can be placed in the isolator as well as plants and animals which he can view through the isolator walls, and arranging for his tutoring at the present time in a nursery school situation.

Whether or not the decision to place this child in the isolator at birth will eventually result in the correction of his disorder cannot yet be assessed. However, much information regarding the basic disorder has already been obtained and the opportunity to obtain further information is inestimable. We now know that it is possible to maintain a severely immunodeficient child free of infection for at least 4 years and that it is possible to have a normal developmental pattern under these conditions. Immunologic, hematologic, and nutritional patterns have been evaluated in this SCID patient, free of the complications of infection. Finally, this is the oldest SCID patient in medical history who has survived without reconstitution. No such opportunity has ever before existed for studies of the basic pathology and evolution of this immune disorder.

\section{REFERENCES AND NOTES}

1. Ackeret, C., Pluss, H. J., and Hitzig, W. H.: Hereditary severe combined immunodeficiency and adenosine deaminase deficiency. Pediat. Res. 10:67 (1976).

2. Ammann, A. J., Wara, D. W., Salmon, S., and Perkins, H.: Thymus transplantation: Permanent reconstitution of cellular immunity in a patient with sex-linked combined immunodeficiency. N. Engl. J. Med. 5: 289 (1973).

3. Bach, F. H. and Voynow, N. K.: One-way stimulation in mixed leukocyte cultures. Science, 153: 545 (1966).

4. Bach, J. F., Dardenne, M., Goldstein, A. L., Guha, A., and White, A.: Appearance of T-cell markers in bone marrow rosette-forming cells after incubation with thymosin, a thymic hormone. Proc. Natl. Acad. Sci. U. S. A., 68: 2734 (1971).

5. Bangs, T., and Garrett, S.: Birth-3 Scale, Experimental Edition (The Speech and Hearing Institute of the University of Texas Health Science Center at Houston, Texas, 1971).

6. Bayley, N.: Bayley Scales of Infant Development (The Psychological Corporation, New York, 1970).

7. Bellak, L., and Bellak, S.: Children's Apperception Test (C. P. S. Inc., Larchmont, N. Y. 1970).

8. Biggar, W. D., Park, B. H., and Good, R. A.: Immunologic reconstitution. Annu. Rev. Med., 24: 135 (1973).

9. Bowlby, J.: Attachment and Loss. Vol. I: Attachment, p. 180 (Basic Books, Inc., New York, 1969).

10. Carrow, E.: Test for Auditory Comprehension of Language (Learning Concepts, Austin, Tex., 1973).

11. Cervenka, J. Gorlin, R. J., and Bendel, R.P.: Prenatal sex determination. Obstet. Gynecol., 37: 912 (1971).

12. Coates, M. E.: Nutrition and Metabolism. In: M. E. Coates: The Germfree Animal in Research, Chapt. 8 (Academic Press, New York, 1968).

13. Criswell, B. S., South, M. A., Jordan, H. W., Kimzey, S. L., Montgomery, J. R. and Heim, L. R.: Fine structure of lymphocytes from an immune deficient child before and after administration of transfer factor. Exp. Hematol., 3: 327 (1975).

14. De Fazio, S. R., Criswell, B. S., Kimzey, S. L., South, M. A., and Montgomery, J. R.: A paraprotein in severe combined immunodeficiency disease detected by immunoelectrophoretic analysis of plasma. Clin. Exp. Immunol., 19: 563 (1975). (Note: De Fazio has now found this paraprotein in a total of seven children with SCID.)

15. Drasar, B. S., Shiner, M., and McLeod, G. M.: Studies on the intestinal flora. 1. The bacterial flora of the gastrointestinal tract in healthy and achlorhydric persons. Gastroenterology, 56: 71 (1969).

16. Dunn, L. M.: Peabody Picture Vocabulary Test (American Guidance Service, Inc., Circle Pines, Minn., 1965).

17. Federlin, K., Maini, R. N., Russell, A. S., and Dumonde, D. C.: A micromethod for peripheral leukocyte migration in tuberculin sensitivity. J. Clin. Pathol',-24: 533 (1971).

18. Freedman, D. A.: Congenital and perinatal sensory deprivations: Their effect on the capacity to experience affect. Psychoanal. Q., 44: 62 (1975).

19. Freedman, D. A., Bealmear, P. M., Montgomery, J. R., South, M. A. and Wilson, R.: Further observations on the effect of reverse isolation from Birth on affective development. J. Amer. Acad. Child Psychiat., 15: 593 (1976).

20. Goldman, R., Fristoe, M., and Woodcock, R.: Goldman-Fristoe-Woodcock Test of Auditory Discrimination (American Guidance Service, Inc., Circle Pines, Minn., 1970).

21. Hitzig, W. H.: Congenital thymic and lymphocytic deficiency disorders. In: E. R. Stiehm and V. A. Fulginiti: Immunologic Disorders in Infants and
Children, Chapt. 14 (W. B. Saunders Company, Philadelphia, 1973).

22. Holland, J.: Slow, inapparent and recurrent viruses. Sci. Amer., (No. 2): 32 (1974).

23. Hoyer, J. R., Cooper, M. D., Gabrielsen, A. E., and Good, R. A.: Lymphopenic forms of congenital immunologic deficiency diseases. Medicine, 47: 201 (1968).

24. Ireton, H. R. and Thwing, E. J.: Minnesota Child Development Inventory (Interpretive Scoring Systems, A Division of National Computer Systems, Minneapolis, 1972).

25. Jondal, M., Holm, G., and Wigzell, H.: Surface markers on human T and B lymphocytes. J. Exp. Med., 136: 207 (1972)

26. Keightley, R. G., Lawton, A. R., and Cooper, M.D.: Successful fetal liver transplantation in a child with severe combined immunodeficiency. Lancet, ii: 850 (1975).

27. Kellogg, T. F.: Microbiological aspects of enterohepatic neutral sterol and bile acid metabolism. Fed. Proc., 30: 1808 (1971).

28. Kirk, S. A., McCarthy, J. J., and Kirk, W.: Illinois Test of Psycholinguistic Abilities (University of Illinois Press, Urbana, III., 1968).

29. Mackler, B. F., Altman, L. C., Rosenstreich, D. L., and Oppenheim, J. J.: Induction of lymphokine production by EAC and of blastogenesis by soluble mitogens during human B-cell activation. Nature, 249: 834 (1974).

30. Mackler, B. F., Altman, L. C., Wahl, S., Rosenstreich, D. L., Oppenheim, J. J., and Mergenhagen, S. F.: Blastogenesis and lymphokine synthesis by T and $B$ lymphocytes from patients with periodontal disease. Infect. Immunol. 10: 844 (1974).

31. Mackler, B. F., O'Neill, P., Richie, E., Mukhopadhyay, N., and Montgomery, J. R.: Cytotoxic and soluble mediator responses by complement (C3) receptor-bearing lymphocytes from patients with B cell immunodeficiency disease. Clin. Immunol. Immunopathol. (In press.)

32. Malinak, L. R., Wilson, R., South, M. A., Montgomery, J. R., Mumford, D. M., and Flowers, C. E.: Germ-free delivery: The initiation of management of infants with a high probability of congenital immune deficiency states. Amer. J. Obstet. Gynecol., 116: 201 (1973).

33. Marples, M. J.: The normal flora of the human skin. Brit. J. Dermatol., 81 (Suppl. 1): 2 (1969).

34. McCarthy, D.: McCarthy Scales of Children's Abilities (The Psychological Corporation, New York, 1972).

35. Meuwissen, H. J., Pollara, B., Pickering, R. J., et al.: Combined immunodeficiency discase associated with adenosine deaminase deficiency. J. Pediat., 86: 169 (1975).

36. Montgomery, J. R., South, M. A., Rawls, W. E., Melnick, J. L., Olson, G. B., Dent, P. B., and Good, R. A.: Viral inhibition of lymphocyte response to phytohemagglutinin. Science, 157: 1067 (1967).

37. Moore, W. E. C., and Holdeman, L. V.: Human fecal flora: The normal flora of twenty Japanese-Hawaiians. Appl. Microbiol., 27: 961 (1974).

38. Moore, W. E. C., Ryser, M., and Holdeman, L. V.: Predominant kinds of bacteria in gastro-intestinal contents. Abstracts of the Annual Meeting. Amer. Soc. Microbiol. p. 61 (1975).

39. Mukopadhyay, N., Richie, E., Mackler B. F., Montgomery, J. R., Wilson R., Fernbach, D. J., and South, M. A.: Longitudinal study of T and B lymphocytes from a three year old patient with severe combined immunodeficiency in gnotobiotic prot sction. (In preparation.)

40. Mukophadhyay, N., Richie, E., Montgomery, J., Wilson, R., Fernbach, D. J., and South, M. A.: Peripheral blood T and B-cell characteristics in a patient with severe combined immune deficiency (SCID) maintained in a gnotobiotic environment. Exp. Hematol., 4: 1 (1976).

41. O'Neill, P., Mackler, B. F., and Wyde, P.: Complement (C3) receptorbearing lymphoycte-mediated cytotoxicity and lymphotoxin responses. Cell Immunol., 20: 33 (1975).

42. Pauly, J. L., and Sokal, J. E.: A simplified technique for in vitro studies of lymphocyte reactivity. Proc. Soc. Exp. Biol. Med., 140: 40 (1972).

43. Rachelefsky, G. S., Stiehm, E. R., Ammann, A. J., Cederbaum, S. D. Opelz, G., and Terasaki, P. I.: T-cell reconstitution by thymus transplantation and transfer factor in severe combined immunodeficiency. Pediatrics, 55: 114 (1975).

44. Rebuck, J. W., and Crowley, J. H.: A method of studying leukocyte functions in vivo. Ann. N. Y. Acad. Sci., 59: 757 (1955).

45. Rorschach, H.: Psychodiagnostic Plates (Grune \& Stratton, Inc., New York, 1921).

46. Simons, C., Köhle, K., Genscher, U., and Dietrich, M.: The impact of reverse isolation on early childhood development. Psychother. Psychosom., 22: 300 (1973).

47. South, M. A., Montgomery, J. R., Wilson, R., Soriano, R., Malinak, L. R., Heim, L. R., and Trentin, J. J.: The Caesarean delivery of an infant with severe combined immune deficiency, and his maintenance in a germ-free isolator. Exp. Hematol., 22: 71 (1972).

48. Stockman, G. D., Gallagher, M. T., Heim, L. R., South, M. A., and Trentin, J. J.: Differential stimulation of mouse lymphoid cells by phytohemagglutinin and pokeweed mitogen. Proc. Soc. Exp. Biol. Med., 136: 980 (1971).

49. Teller, W. M., et al.: Rearing of non-identical twins with lymphopenic hypogammaglobulinaemia under gnotobiotic conditions. Acta Paediat. Scand. Suppl., 240: 1 (1973).

50. Terman, M., and Merrill, M. A.: Stanford-Binet Intelligence Scale, 3rd Revision (Houghton Mifflin Co., Boston, 1972).

51. United States Interdepartmental Committee on Nutrition for National Defense, Manual for Nutrition Surveys, 2nd Ed (United States Government Printing Office, Bethesda, Md., 1963). 
52. Whisnant, J. K., Schiff, R. I., Gilbertson, R. B., Platt, M. S., and Buckley, R. H.: Fetal liver transplantation in severe combined immunodeficiency: Success and graft versus host disease [Abstract]. Pediat. Research, 9: 336 (1975).

53. Williams, R. E. O., and Drasar, B. S.: Alterations in gut bacterial flora in disease. In: J. Badenoch and B. N. Brooke: Recent advances in Gastroenterology, p. 31 (The Wiliams and Wilkins Co., Baltimore, 1972).

54. Wilson, R., South, M. A., Malinak, L. R., Lawton, A. R., Cooper, M. D. and Flowers, C. E., Jr.: A simplified plastic flexible film isolator system for the germfree delivery and maintenance of infants with immune deficiency. In: J. B. Heneghan: Germfree Research-Biological Effect of Gnotobiotic Environments, p. 477 (Academic Press, New York, 1973).

55. Yunis, E. J., Amos, D. B.: Three closely linked genetic systems relevant to Transplantation. Proc. Natl. Acad. Sci. U. S. A., 68: 3031 (1971).

56. Assistance in the search for histocompatible donors was received from Dr. John Barrett, Dr. Bo DuPont, Dr. L. J. Dooren, Dr. J. J. van Roods, and Dr. Paul Terasaki.

57. The flexible film units were built by the Standard Safety Equipment Company Palantine, Ill. The intermediate play isolator was built by Frank Lucas, Co. Houston, Texas. The rigid walled playroom was built by Ecodyne Systems, Inc., Houston, Texas, based on a modification of a standard patient isolator developed by Linear Flow Systems of Grand Rapids, Mich.

58. Microbiological monitoring: to the age of 28 months in the Pathology Laboratory of Texas Children's Hospital and the Division of Experimental Biology of Baylor College of Medicine, Houston; after 28 months, in special circumstances such as accidents or breaks in the system, in the C. T. Parker Laboratories, Pediatric Department, Baylor College of Medicine, Houston; after 38 months, at the Microbiological Laboratories, Johnson Space Center, Division of National Aeronautics and Space Administration, Houston, Tex.

59. The Mobile Biological Isolation Systems suit was designed and fabricated at the Johnson Space Center, Division of National Aeronautics and Space Administration, Houston, Tex.

60. Kindly done by Dr. Ulf Nilsson.

Copyright 1977 International Pediatric Research Foundation, Inc.
61. Kindly done by Drs. J. F. Bach and Allan Goldstein.

62. Kindly done by Drs. H. J. Meuwissen and Ben Pollara.

63. The data, beginning at 2 years of age, was collected by Nalini Mukhopakhyay and confirmed by Drs. Max Cooper, Nabih Abdou, and Sue Criswell.

64. Kindly done by Drs. Max Cooper and A. R. Lawton (cited in Amer. J. Pathol., 69: 513 (1972).

65. Thymosin was kindly supplied by Dr. Allan Goldstein.

66. From Microbiological Associates Inc., Bethesda, Md.

67. Assays of the sensitivity of the Meloy IgA plates and IgA assays on the patient from 28-43 months were done by Dr. Edward $O$. Mason.

68. Dr. Evan Hersh kindly supplied the KLH and did the antibody titers.

69. Kindly done by Dr. William McGannity.

70. This child was maintained in Texas Children's Hospital, Houston, in the Clinical Research Center supported by Clinical Research Center Grant M01 RR00188 of the United States Public Health Service. Research studies were also supported by United States Public Health Service Grants RR-3212 AI08227, K4-AI-238230, DE-02232, DE-04210, DE-04712, GRS-5-S01RR-05344 (13), 1-T22-DE-00035-01, CC-00406; National Cancer Institute Grants CA-12093, K6-CA-14219, CA-03367, CA-07357; National Aeronautics and Space Administration Grant NGR-44-003-044 National Aeronautics and Space Administration and Contracts NAS-9-1300, NAS-13139; Research Hematology Fund, Texas Children's Hospital; Cellular Immunology Fund, Baylor College of Medicine; The Houston Chapter of the National Foundation; Private Contributions from Anonymous Donors.

71. The present address of Dr. J. R. Montgomery is: Ambulatory Care Center, School of Primary Medical Care, University of Alabama, Huntsville, Ala. 35801 (USA).

72. The present address of Dr. M. A. South is: Allergy and Immunology Section, Children's University of Pennsylvania, Philadelphia, $\mathrm{Pa} .19104$ (USA)

73. Requests for reprints should be addressed to: $A$. Williamson, Department of Pediatrics, Baylor College of Medicine, Texas Medical Center, Houston, Tex. 77030 (USA).

74. Received for publication March 26, 1976

75. Accepted for publication July $21,1976$. 